\title{
WILLIAMS SYNDROME. DEVELOPMENT OF A NEW SCORING SYSTEM FOR CLINICAL DIAGNOSIS
}

\author{
Sofia Mizuho Miura Sugayama, Cláudio Leone, Maria de Lourdes Lopes Ferrari \\ Chauffaille, Thelma Suely Okay, Chong Ae Kim
}

\begin{abstract}
Sugayama SMM, Leone C, Chauffaille M de LLF, Okay TS, Kim CA. Williams syndrome. development of a new scoring system for clinical diagnosis. Clinics. 2007:62(2):159-66.
\end{abstract}

OBJECTIVE: To develop a scoring system based on clinical findings to assist pediatricians in the diagnosis of William syndrome and to delineate when the fluorescent in-situ hybridization test to detect the microdeletion at 7q11.23 may be needed.

METHODS: The fluorescent in-situ hybridization test was performed on 20 patients presenting William syndrome suggestive clinical features. Eleven studies were selected from the literature in which there were 2 groups: patients with positive or negative fluorescent in-situ hybridization tests. Forty-two clinical characteristics were compared to those reported in the literature to determine which ones were associated with the affected patients (ie, bearing deletions) using meta-analysis. The 2-tailed Fisher exact test were used so that the frequency of findings observed in fluorescent in-situ hybridization positive and fluorescent in-situ hybridization negative patients could be compared in the present study together with the patients from the literature. We developed a scoring system based on clinical findings and their significant associations with patients with positive fluorescent in-situ hybridization tests. From the mean and standard-deviation values of the data from our patients, we determined the cut-off score that that indicated the need for a fluorescent in-situ hybridization test to confirm diagnosis.

RESULTS: Seventeen patients were fluorescent in-situ hybridization positive, and 3 were fluorescent in-situ hybridization negative. The more discriminative findings among fluorescent in-situ hybridization positive patients were the following: typical facies, low birth weight, feeding difficulties, constipation, supravalvar aortic stenosis, mental retardation, and friendly personality. The distribution of the points among the 20 patients ranged from 19 to 28 points with a mean value of 23.3 out of a possible total of 31 points. The cut-off score that indicated the need for a fluorescent in-situ hybridization test was 20.

CONCLUSIONS: Our scoring system enables physicians to differentiate between those individuals who can be reliably diagnosed as having Williams syndrome solely from the clinical findings and those who need to undergo fluorescent in-situ hybridization testing for a correct diagnosis.

KEYWORDS: Williams syndrome. Chromosome 7. In-situ hybridization. Elastin gene.

\section{INTRODUCTION}

Williams syndrome (WS), also known as WilliamsBeuren syndrome (WBS), is rare (1:20,000 to 1:50,000 live births $)^{1}$ and is characterized by multiple anomalies including typical facial dysmorphisms, congenital heart defects, growth deficiency, mental retardation (MR), and occasionally infantile hypercalcemia. ${ }^{2,3}$ Williams syndrome is con-

Child's Institute, São Paulo University Medical School - São Paulo/SP, Brazil. Email: sofiamms@uol.com.br

Received for publication on August 25, 2006.

Accepted for publication on December 12, 2006. sidered a segmental aneusomy due to a hemizygous deletion of a contiguous gene at the long arm of chromosome 7 (7q11.23). ${ }^{4,5}$ Most individuals with WS (99\%) have a 1.5 megabase deletion in 7q11.23 encompassing the elastin gene (ELN) and 25-35 other genes, ${ }^{5,6}$, all of which is detectable by fluorescent in situ hybridization (FISH). ${ }^{7,8}$

Diagnosis of WS is made by clinical evaluation, usually during infancy, when the typical facial characteristics become more evident, becoming recognizable as early as 4 months of age. ${ }^{9}$ The FISH test is useful for confirming the diagnosis because the broad phenotypic spectrum hinders the making of a diagnosis, especially in the first year 
of life. This study is part of an institutional project which aims at establishing the genetic basis if prevalent congenital anomalies ${ }^{10}$ and its purpose was to develop a scoring system based on objective clinical findings of WS patients to assist general pediatricians in making a clinical diagnosis of the disease.

\section{METHODS}

Twenty patients who presented suggestive clinical features of WS were included. The mean age at the time of the diagnosis was 5.9 years. Karyotypes of lymphocytes from a peripheral blood sample were evaluated using Giemsa-Trypsin-Giemsa banding. Hemizygosity for the elastin gene was identified using FISH (fluorescence in-situ hybridization) with the LSI Williams Syndrome Region DNA probe (VYSIS $®)$ (Figures 1, 2, and 3a,b) as described elsewhere. ${ }^{11}$

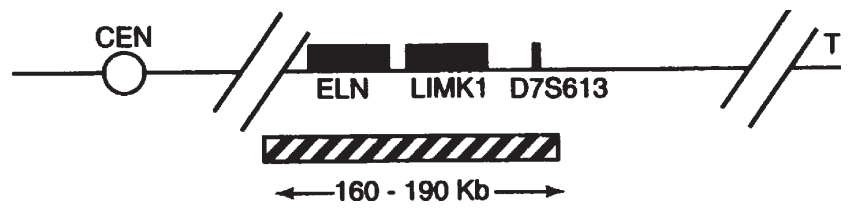

Figure 1 - Region 7q11.23 on the long arm of chromosome 7 and probe VYSIS ${ }^{\circledR}$ LSI Williams Syndrome

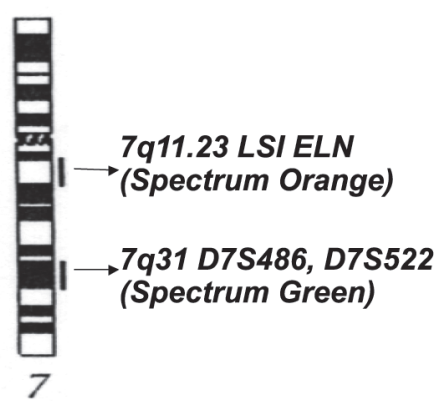

Figure 2 - Chromosome 7 ideogram: regions of probe hybridization

We also performed a meta-analysis of 11 studies selected from the literature to establish the clinical features that are associated with FISH-positive patients; these studies were those of Borg et al (1995), ${ }^{12}$ Brewer et al (1995), ${ }^{13}$ Kotzot et al (1995), ${ }^{14}$ Lowery et al (1995), ${ }^{15}$ Nickerson et al (1995), ${ }^{16}$ Joyce et al $(1996)^{17}$, Perez Jurado et al (1996), ${ }^{18}$ Brondum-Nielsen et al (1997), ${ }^{19}$ Elcioglu et al (1998); ${ }^{20}$ Mila et al (1999), ${ }^{21}$ and Beust et al (2000). ${ }^{22}$ A total of 597 patients with WS were analyzed (including 20 patients of our sample), and among them, 361 individuals had the microdeletion of the ELN locus. We selected works that were similar to our study, ie, with the frequency of clini-
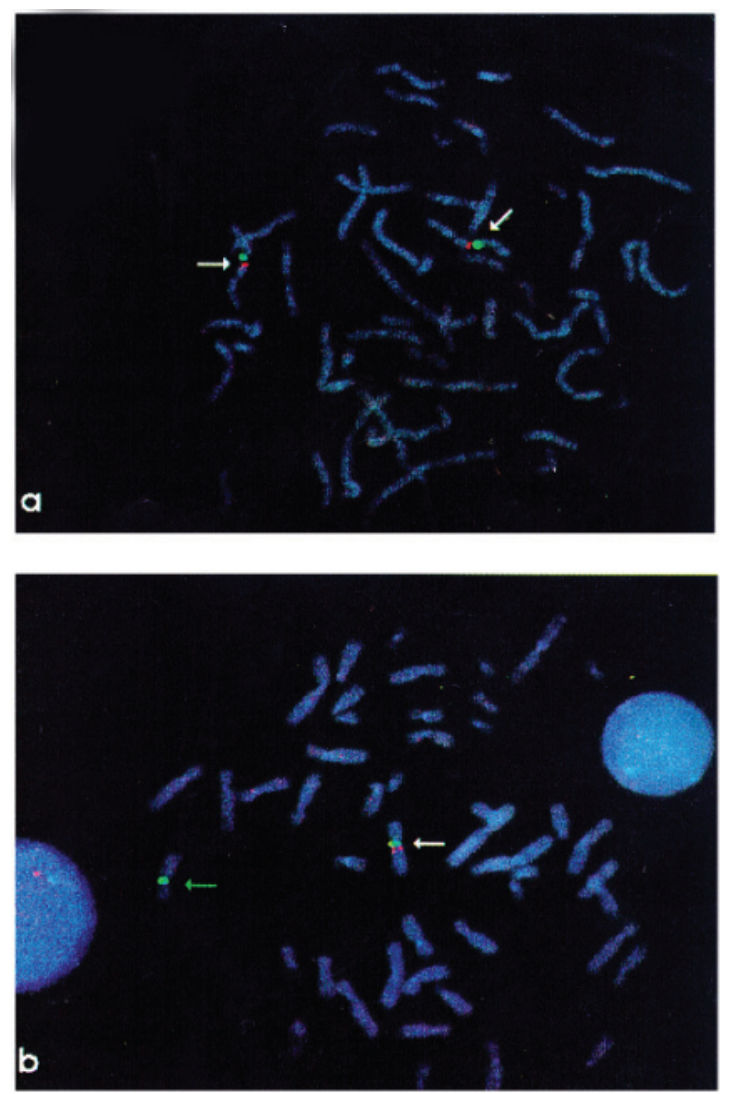

Figure 3 - a: Picture of FISH test for WS demonstrating metaphase with 2 red signals (elastin gene) and 2 green signals (markers of chromosome 7), therefore without elastin gene deletion (FISH-negative patient). b: Picture of FISH test for WS demonstrating metaphase with 2 green signals (markers of chromosome 7) and only 1 red signal (elastin gene); therefore, with deletion of the elastin gene (FISH-positive patient).

cal features being categorized into 2 groups: individuals that were FISH-positive or FISH-negative.

Forty-two clinical characteristics were analyzed from 577 patients as follows: low birth weight, feeding difficulties, failure to thrive, vomiting, obstipation, bitemporal narrowing, broad forehead, periorbital fullness, flat malar, full cheeks, low nasal root, short upturned nose, long philtrum, wide mouth, thick lips, small jaw, dental anomalies, hoarse voice, strabismus, stellate iris pattern, supravalvular aortic stenosis (SVAS), pulmonary artery stenosis, mitral valve prolapse, aortic coarctation, non-SVA congenital heart disease, umbilical/inguinal hernia, kidney anomalies, arterial hypertension, hypercalcemia, joint contractures, fifth finger clinodactyly, hypoplastic nails, short stature, microcephaly, hypotonia, developmental delay, hyperacusis, mental retardation, overfriendliness, hyperactivity, anxiety, and loquaciousness.

We used the 2-tailed Fisher exact test to compare the frequencies of WS clinical characteristics presented by our patients that were FISH-positive and Fish-negative as well 
as those reported in the literature using meta-analysis. ${ }^{22} \mathrm{We}$ considered an association between WS clinical findings and the presence of a microdeletion at elastin gene locus to be statistically significant when $P<0.001$.

The level of significance ( $\alpha=0.05)$ was adjusted using Bonferroni's correction for multiple comparisons. This was accomplished by dividing the significance level $(\alpha=$ 0.05 ) by the total number of pair-wise comparisons of the presence of the microdeletion with the clinical characteristics (42). Using such a stringent significance level reduces the chances of a type I error or the Bonferroni's effect. Bonferroni's correction is used when multiple dependent or independent statistical tests are performed simultaneously. Although a certain alpha value may be appropriate for each individual comparison, it is not appropriate for the set of all comparisons. In order to avoid a large number of false positives, the alpha values needs to be lowered to account for the numbers of comparisons being performed..$^{23,24}$

We developed a scoring system (Table 1) based on the clinical findings for which meta-analysis showed a significant association $(P<0.001)$ with FISH-positive tests. We also included clinical findings with the significance level close to the adjusted " $\alpha$ " using Bonferroni's correction in order to have a larger number of objective variables, which facilitates the WS diagnosis for general pediatricians. The scoring was done as follows: 3 points for the clinical findings with a significance level under $P<0.001,2$ points for characteristics with $P$ close (although not statistically significant) to the adjusted " $\alpha$ " using Bonferroni's correction; and 1 point for the features with $P$ close to the $\alpha$ without using correction for Bonferroni's error (ie, $\alpha=0.05$ ), which would have been significant if $P$ had not been corrected. We decided to exclude some features that might have been included in the scoring system exclusively by

Table 1 - Phenotype scoring system of the present work

\begin{tabular}{ll}
\hline Characteristics & Points \\
\hline Low birth weight & 3 \\
Feeding difficulties & 3 \\
Obstipation & 3 \\
Typical face & 3 \\
SVAS & 3 \\
Mental deficiency & 3 \\
Overfriendliness & 3 \\
Strabismus & 2 \\
Developmental delay & 2 \\
Failure to thrive & 1 \\
Non-SVAS congenital heart disease & 1 \\
Arterial hypertension & 1 \\
Joint contractures & 1 \\
Hyperacusis & 1 \\
Hypoplastic nails & 1 \\
Total & 31 \\
\hline
\end{tabular}

SVAS = supravalvular aortic stenosis these criteria, because these features cannot be objectively characterized. The Kolmogorov-Smirnov method was used to check whether the values obtained by the scoring system presented a Gaussian distribution. ${ }^{23}$ We correlated the scores with the percentiles, based on the means and standard-deviations of the data collected from the 20 patients of the present study.

\section{RESULTS}

The GTG-stained karyotype was normal in all 20 patients. The deletion of the elastin gene was found in 17 out of 20 patients. In both groups, the main complaints were the failure to thrive and feeding difficulty. Constipation was observed in $59 \%$ of FISH-positive patients. All patients presented typical facies (Figure 4a, b). Dental anomalies, hoarse voice, strabismus, stellate pattern of the iris, and retinal vessel tortuosity were observed only in FISH-positive
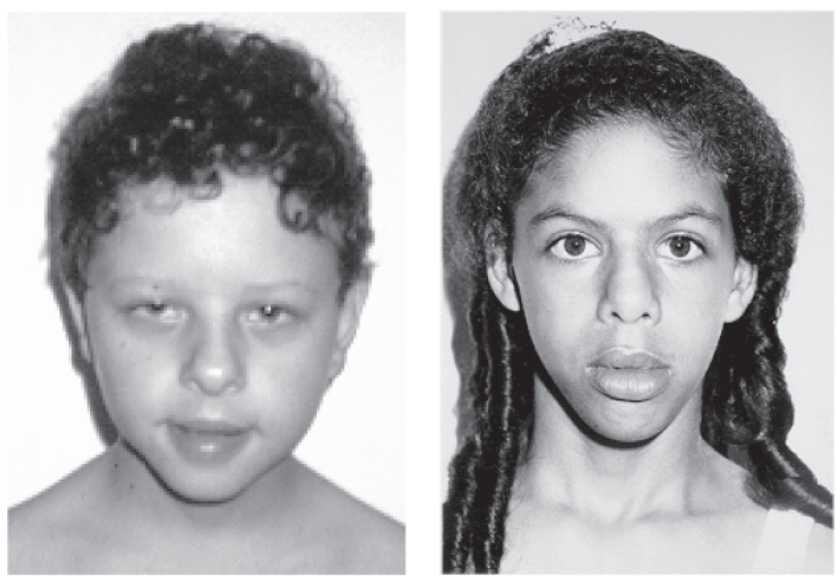

Figure 4a - Two patients (cases 1 and 2) with typical craniofacial features of WS at 9 years of age.
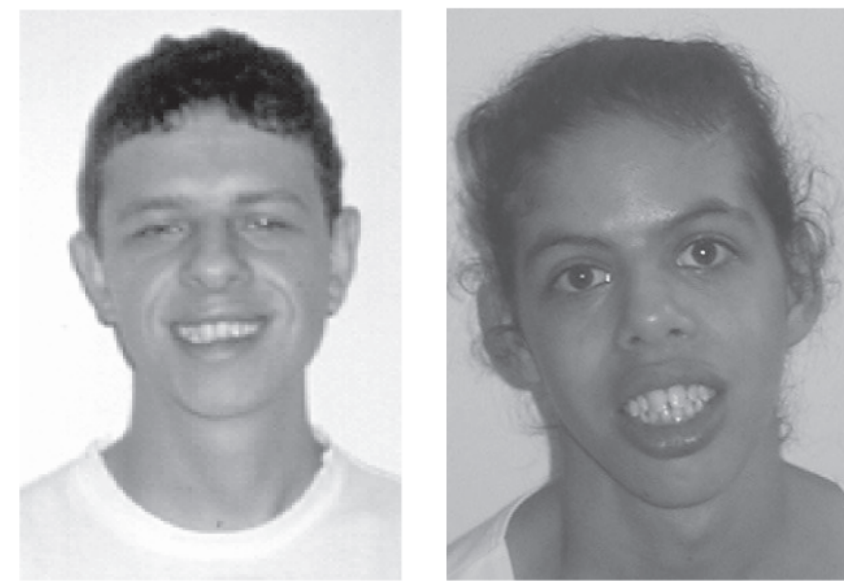

Figure $4 \mathbf{b}$ - Two patients (cases 1 and 2) of WS at 19 years of age. The face has become more elongated, the supraorbital ridges are more prominent, and the lips have thickened. Both patients showed premature wrinkling of the skin. 
patients. Cardiac abnormalities were diagnosed in all patients who were FISH-positive except 1, but they were absent in FISH-negative patients. The most frequent cardiac defects were supravalvar aortic stenosis (SVAS), branch pulmonary stenosis, and mitral valve prolapse. Additionally, inguinal and umbilical hernias were detected in $41 \%$ of FISH-positive patients and in 1 FISH-negative individual. Renal anomalies were diagnosed in 5/17 FISH-positive patients and in 1 individual from the FISH-negative group. Hypertension was diagnosed in 3 patients with genomic deletions and in none of the patients without deletions. Although hypercalcemia was not observed in our sample, intermittent hypercalciuria was detected in 4 out of 17 FISHpositive patients and in 2 out of the 3 FISH-negative ones. All patients presented hypotonia, delayed psychomotor development, and motor uncoordination. Hyperacusia was found in 59\% of the FISH-positive patients and in none of the FISH-negative group. Mental retardation (MR) and the friendly personality occurred in $95 \%$ of all patients, ie, in all patients with genomic deletions and in 2 of the 3 patients without deletions.

The details of the scoring system are as follows (see also Table 1):

- The occurrence of typical facial dysmorphisms (bitemporal narrowing, broad forehead, periorbital fullness, full cheeks, short upturned nose, long philtrum, wide mouth, thick lips), failure to thrive, feeding difficulties, constipation at infancy, dental anomalies, SVAS, MR, and friendly personality were significantly more frequent $(P<0.001)$ in the group with genomic deletions than in the group without deletions; these characteristics were assigned a score of 3 .
- Strabismus, low nasal root, flat malar, and developmental delay showed significant association with genomic deletions by univariate analysis at $\alpha=0.05$. The $P$ values were close to the adjusted alpha value when using Bonferroni's correction; these characteristics were assigned a score of 2 .

- Failure to thrive, non-SVAS congenital heart disease, arterial hypertension, joint contractures, hyperacusis, and hypoplastic nails showed a significant association on univariate analysis at $\alpha=0.05$, but the $P$ values were closer to the $\alpha$ value than the value corrected for Bonferroni's error; these characteristics were assigned a score of 1 .

Attributing the score according to the values described, the total scores in the 17 FISH-positive patients ranged from 19 (case 1) to 28 points (cases 8 and 13) out of a possible total score of 31 . The scores in the 3 FISH-negative patients were 12 (case 6), 15 (case 9), and 16 (case 16). (Table 2 shows the individual scoring for our sample). The mean value of the distribution curve of total points from our patients was 23.3 (median 24) and the standard deviation was 2.8 . The $95 \%$ confidence interval of the mean was 17.8 (lower limit) to 24.7 (upper limit).

The 25 percentile of the score curve distribution was 18 points. To increase the accuracy of the scoring system, we elected to establish the cut level at 20 points because this value was between the 10 and 15 percentiles of the Gaussian curve. Thus, the probability of a patient with a value equal or higher than 20 points having a negative FISH test would be low in our scoring system. Therefore, the FISH test would be indicated for individuals suspected of having WS, but having a total score of less than 20 points.

Table 2 - Phenotype scoring system of the present work applied with our 20 patients

\begin{tabular}{|c|c|c|c|c|c|c|c|c|c|c|c|c|c|c|c|c|c|c|c|c|}
\hline \multirow[b]{2}{*}{ Characteristics } & \multirow[b]{2}{*}{1} & \multirow[b]{2}{*}{2} & \multirow[b]{2}{*}{3} & \multirow[b]{2}{*}{4} & \multirow[b]{2}{*}{5} & \multirow[b]{2}{*}{6} & \multirow[b]{2}{*}{7} & \multirow[b]{2}{*}{8} & \multirow[b]{2}{*}{9} & \multicolumn{2}{|c|}{ Patients } & \multirow[b]{2}{*}{12} & \multirow[b]{2}{*}{13} & \multirow[b]{2}{*}{14} & \multirow[b]{2}{*}{15} & \multirow[b]{2}{*}{16} & \multirow[b]{2}{*}{17} & \multirow[b]{2}{*}{18} & \multirow[b]{2}{*}{19} & \multirow[b]{2}{*}{20} \\
\hline & & & & & & & & & & 10 & 11 & & & & & & & & & \\
\hline Low birth weight & - & + & + & - & - & - & + & + & - & - & + & - & + & + & + & - & + & - & - & + \\
\hline Feeding difficulties & - & + & + & + & + & + & + & + & + & + & + & + & + & - & + & + & - & + & + & + \\
\hline Obstipation & - & - & + & - & + & - & - & + & - & + & - & + & + & + & - & - & + & + & - & + \\
\hline Typical facies & + & + & + & + & + & + & + & + & + & + & + & + & + & + & + & + & + & + & + & + \\
\hline SVAS & + & - & + & + & - & - & + & + & - & + & + & + & + & + & + & - & - & - & + & + \\
\hline Mental deficiency & + & + & + & + & + & - & + & + & + & + & + & + & + & + & + & + & + & + & + & + \\
\hline Overfriendliness & + & + & + & + & + & - & + & + & + & + & + & + & + & + & + & + & + & + & + & + \\
\hline Strabismus & - & - & - & - & - & - & + & + & - & + & - & + & + & - & + & - & + & + & + & - \\
\hline Developmental delay & + & + & + & + & + & + & + & + & + & + & + & + & + & + & + & + & + & + & + & + \\
\hline Failure to thrive & + & + & + & + & + & + & + & + & + & + & + & + & + & + & + & + & + & + & + & + \\
\hline Non-SVAS congenital heart disease & - & + & - & - & + & - & - & - & - & - & - & - & - & - & - & - & + & + & - & - \\
\hline Arterial hypertension & + & - & - & - & - & - & - & - & - & - & + & - & - & + & - & - & - & - & - & - \\
\hline Joint contractures & + & - & - & - & - & - & - & + & - & - & - & - & - & + & - & - & - & - & - & - \\
\hline Hyperacusis & + & + & + & + & + & - & + & + & - & + & + & + & + & + & - & + & + & + & + & + \\
\hline Hypoplastic nails & + & + & - & - & - & - & - & - & - & - & - & - & + & - & + & - & + & - & - & - \\
\hline Total & 19 & 21 & 25 & 19 & 20 & 12 & 24 & 28 & 15 & 24 & 23 & 24 & 28 & 24 & 24 & 16 & 23 & 22 & 21 & 27 \\
\hline
\end{tabular}

SVAS $=$ supravalvular aortic stenosis 


\section{DISCUSSION}

The proportion of the FISH-positive patients and FISHnegative ones in the present work and the patients from the literature used in performing meta-analysis are listed in Table 3. We observed that in those works in which the frequency of FISH-positive tests was low in comparison with the majority of the studies, there was not a strict clinical criterion for carrying out the FISH test. Joyce et al (1996) ${ }^{17}$ performed FISH on a series of 52 patients divided into 3 groups: 23 classical WS individuals; 22 atypical patients with suspected WS; and 7 patients with isolated SVAS and peripheral pulmonary stenosis. In the classical WS group, $22 / 23$ (96\%) had a microdeletion at the ELN locus. In the suspected WS group 2/22 (9\%) patients were found with the microdeletion. Among 7 patients with isolated SVAS and peripheral pulmonary stenosis, the FISH test was positive in only 1/7 (14\%) individual with SVAS. In the sample of Brondum-Nielsen et al, ${ }^{19}$ 19/24 FISH-positive patients with suspected WS had typical manifestations of WS. None of the 20 FISH-negative individuals presented typical features of WS, and FISH was carried out due to the developmental delay and the presence of some suggestive characteristics of WS.

Table 3 - Frequency of patients with Williams syndrome that were FISH-positive and FISH-negative from the literature, and for our patients

\begin{tabular}{llll}
\hline Author (year) & $\begin{array}{l}\text { Positive } \\
\text { FISH }\end{array}$ & $\begin{array}{l}\text { Negative } \\
\text { FISH }\end{array}$ & Total \\
\hline Borg et al (1995) & $8(80 \%)$ & $2(20 \%)$ & $10(100 \%)$ \\
Kotzot et al (1995) & $22(75 \%)$ & $7(25 \%)$ & $29(100 \%)$ \\
Nickerson et al (1995) & $39(91 \%)$ & $7(9 \%)$ & $43(100 \%)$ \\
Lowery et al (1995) & $110(96 \%)$ & $4(4 \%)$ & $195(100 \%)$ \\
Joyce et al (1996) & $24(53 \%)$ & $21(47 \%)$ & $45(100 \%)$ \\
Brewer et al (1996) & $16(94 \%)$ & $1(6 \%)$ & $17(100 \%)$ \\
Perez Jurado et al (1996) & $61(94 \%)$ & $4(6 \%)$ & $65(100 \%)$ \\
Brondum-Nielsen et al (1997) & $24(54 \%)$ & $20(46 \%)$ & $44(100 \%)$ \\
Elçioglu et al (1998) & $14(80 \%)$ & $2(20 \%)$ & $16(100 \%)$ \\
Mila et al (1999) & $28(45 \%)$ & $41(55 \%)$ & $69(100 \%)$ \\
Beust et al (2000) & $15(34 \%)$ & $29(66 \%)$ & $44(100 \%)$ \\
Sugayama et al (2007) & $17(85 \%)$ & $3(15 \%)$ & $20(100 \%)$ \\
Total & $378(63 \%)$ & $141(24 \%)$ & $97(100 \%)$ \\
\hline
\end{tabular}

The 9 characteristics (low birth weight, feeding difficulties, obstipation during infancy, typical facial features, dental anomalies, hoarse voice, SVAS, MR, and friendly personality) that showed a significant difference between FISH-positive patients and FISH-negative ones are classical features of WS. ${ }^{7,8}$ These characteristics had been described before the discovery of the microdeletion at $7 \mathrm{q} 11.23 .2,3$

Low birth weight is attributed to intra-uterine growth retardation, which was found for most FISH-positive patients of the studies selected by us for meta-analysis. Feeding difficulties and obstipation were also present with increased frequency in FISH-positive individuals from the selected studies, and these are also commonly observed complications associated with hypercalcemia during infancy. ${ }^{9}$ However, hypercalcemia did not show a significant difference between FISH-positive patients and FISH-negative ones in the meta-analysis because it has been documented in the general population at a low frequency.

Although the typical facial features were presented by most of the individuals with suspicion of WS, this characteristic was discriminating between patients bearing microdeletion. We attribute this fact to some investigations that had carried out FISH testing in a great number of patients without the facial dysmorphisms characteristic of WS. Most of these individuals presented developmental delay, MR, or hypercalcemia and some of the 11 facial features that comprise the typical facial aspects of WS.

Supravalvar aortic stenosis was significantly associated with microdeletion because the frequency of this cardiac defect was very low in the large number of FISH-negative patients. The frequency of hoarse voice in FISH-negative patients was very low in the studies of Joyce et al, ${ }^{17}$ Mila et $\mathrm{al}^{21}$ and Beust et $\mathrm{al}^{22}$ and was absent in FISH-negative patients in the study of Borg et $\mathrm{al}^{12}$ and in our sample.

There are 4 phenotype scoring systems for WS in the literature. Preus $(1985)^{26}$ studied 52 patients with a clinical suspicion of WS and elaborated a detailed system based on 50 clinical features, most of them consisting of minor facial dysmorphisms and analyses of dermatoglyphics. Lowery et al (1995) $)^{8}$ developed a phenotype scoring system based on 6 clinical findings of 110 patients with WS having microdeletion at 7q11.23 confirmed by the FISH test. The patients with 4 to 10 points in this scoring system were thought to have "classic WS" and those with points between 0 and 3 were considered to be "uncertain" as to having a WS diagnosis.

We did not use the Preus score for our sample because of the complexity and the presence of several subjective characteristics. And the phenotype scoring system proposed by Lowery et al did not discriminate between typical and atypical patients of our sample because the total score of FISH-positive and -negative patients was classified in the same category as the classic WS phenotype.

A clinical scoring system for WS based on a study of 107 patients with WS confirmed by the FISH test has been proposed (The Health Care Supervision for Children with Williams syndrome (2001) ${ }^{27}$ from the Committee on Genetics of American Academy of Pediatrics). This scoring system is divided into 7 items: growth, behavior, develop- 
ment, facial features, cardiovascular problems, connective tissue abnormality, and calcium studies.

The early diagnosis of WS is essential for adequate management of cardiovascular, renal and urinary ${ }^{28}$ complications, including risk of sudden death..$^{29,30}$ Considering the variability of WS expression, we developed a simplified scoring system with objective clinical features to facilitate the clinical diagnosis for general pediatricians who are not familiar with WS.
Thus, according to Table 1, the presence of features resulting in 20 points is strongly suggestive of WS, while total points below this value would indicate the need to carry out the FISH test to establish the appropriate diagnosis.

\section{ACKNOWLEDGMENTS}

The authors are grateful to Kikue Terada Abe, $\mathrm{PhD}$, for performing the FISH tests.

\section{RESUMO}

Sugayama SMM, Leone C, Chauffaille M de LLF, Okay TS, Kim CA. Síndrome de Williams: proposta de sistema de pontuação para diagnóstico clínico. Clinics. 2007:62(2):159-66.

OBJETIVOS: Desenvolver um sistema de pontuação (Score) baseado nos achados clínicos para auxiliar os pediatras no diagnóstico clínico da Síndrome de WilliamsBeuren e na indicação do teste de hibridização in situ por fluorescência para detectar a microdeleção em 7q11.23.

MÉTODOS: O teste de hibridização in situ por fluorescência foi feito em 20 acometidos pela Síndrome de Williams-Beuren, nos quais 42 achados clínicos foram estudados. Para estabelecer quais desses achados estariam associados ao teste de hibridização in situ por fluorescência positivo, realizou-se uma metanálise com 11 trabalhos da literatura em que havia dois grupos, hibridização in situ por fluorescência positivo e negativo. As freqüências dos achados presentes nos indivíduos fluorescência positivo e fluorescência negativo neste estudo foram comparadas em conjunto com os pacientes da literatura através do teste exato de Fisher. Elaboramos um sistema de pontuação (score) baseado nos achados que mostraram correlação significante $(\mathrm{p}<0,001)$ para os pacientes hibridização in situ por fluorescência positivo. Determinamos os valores correspondentes aos percentis baseados na média e desvio-padrão, calculados a partir dos 20 pacientes do presente trabalho.

RESULTADOS: Dezessete pacientes foram hibridização 
in situ por fluorescência positivo e três, negativo. Os achados mais discriminativos nos hibridização in situ por fluorescência positivo (3 pontos no score) foram: fáceis típico, baixo peso ao nascimento, dificuldades alimentares, obstipação, estenose aórtica supravalvar, deficiência mental e personalidade amigável. A distribuição dos valores entre os 20 pacientes variou de 19 a 28 pontos com uma média de 23,3 pontos.
CONCLUSÕES: O score elaborado permitiu propor o valor de 20 pontos para a indicação do teste de hibridização in situ por fluorescência nos pacientes com suspeita clínica de Síndrome de Williams-Beuren.

UNITERMOS: Síndrome de Williams-Beuren. Cromossomos humanos par 7. Hibridização in situ. Gene da elastina.

\section{REFERENCES}

1. Stromme P, Bjornstad PG, Ramstad K. Prevalence estimation of Williams syndrome. J Child Neurol. 2002;17:269-71.

2. Williams JCP, Barratt-Boyes BG, Lowe JB. Supravalvular aortic stenosis. Circulation 1961;21:1311-18.

3. Beuren AJ. Supravalvular aortic stenosis: a complex syndrome with and without mental retardation. Birth Defects: OAS VIII 1962;5:45-56.

4. Bayés M, Magano LF, Rivera N, Flores R, Pérez Jurado LA. Mutational mechanisms of Williams-Beurens syndrome. Am J Hum Genet, 2003;73:131-51.

5. Merla G, Ucla C, Guipponi M, Reymond A. identification of additional transcripts in the Williams-Beuren syndrome critical region. Hum Genet. 2002;110:429-38

6. Merla G, Howald C, Henrichsen CN, Lyle R, Wyss C, Zabot M-T, et al. Submicroscopic deletion in patients with Williams-Beuren syndrome influences expression levels of the nonhemizygous flanking genes. Am J Hum Genet. 2006;79:332-41.

7. Ewart AK, Morris C A, Atkinson D, Jin W, Sternes K, Spallone P, et al. Hemizygosity at the elastin locus in a developmental disorder, Williams syndrome. Nat Genet. 1993;5:11-6.

8. Lowery MC, Morris CA, Ewart A, Brothman LJ, Zhu XL, Leonard CO, et al. Strong correlation of elastin deletions, detected by FISH, with Williams syndrome: evaluation of 235 patients. Am J Hum Genet. 1995;57:49-53.
9. Morris CA, Demsey AS, Leonard CO, Dilts C, Blackborn. Natural history of Williams syndrome: physical characteristics. J Pediatr. 1988;113:318-26.

10. Okay TS, Oliveira WP, Raiz-Junior R, Rodrigues JC, Del Negro GMB. Frequency of the DF508 mutation in 108 cystic fibrosis patients in São Paulo: comparison with reported Brazilian data. Clinics. 2005; 60(2):131-134.

11. Pinkel, D, Straume, T, Gray, JW. Cytogenetic analysis using quantitative, high sensitivity fluorescence hybridization. Proc Natl Sci USA. 1986;83:2934-8.

12. Borg I, Delhanty JDA, Baraitser M. Detection of hemizygosity at the elastin locus by FISH analysis as a diagnostic test in both classical and atypical cases of Williams syndrome. J Med Genet. 1995;32:692-6.

13. Brewer CM, Morrison N, Tolmie JL. Clinical and molecular cytogenetic (FISH) diagnosis of Williams syndrome. Arch Dis Child. 1996; 74:5961.

14. Kotzot D, Bernasconi F, Brecevic L, Robinson WP, Kiss P, Kosztolanyi $\mathrm{G}$, et al. Phenotype of the Williams-Beuren syndrome associated with hemizygosity at the elastin locus. Eur J Pediatr. 1995;154:477-82.

15. Lowery MC, Morris CA, Ewart A, Brothman LJ, Zhu XL, Leonard CO, et al. Strong correlation of elastin deletions, detected by FISH, with Williams syndrome: evaluation of 235 patients. Am J Hum Genet. 1995;57:49-53. 
16. Nickerson E, Greenberg F, Keating M T, McCaskill C, Shaffer L G. Deletions of the elastin gene at $7 \mathrm{q} 11.23$ occur in $~ 90 \%$ of patients with Williams syndrome. Am J Hum Genet. 1995;56:1156-61.

17. Joyce CA, Zorich B, Pike SJ, Barber JCK, Dennis NR. Williams-Beuren syndrome: phenotypic variability and deletions of chromosomes 7, 11, and 22 in a series of 52 patients. J Med Genet. 1996;33:986-92.

18. Perez Jurado LA, Peoples R, Kaplan P, Hamel CJ, Francke U. Molecular definition of the chromosome 7 deletion in Williams syndrome and parent-of-origin effects on growth. Am J Hum Genet. 1996;59:781-92.

19. Brondum-Nielsen K, Beck B, Gyftidimou J, Horlyk H, Liljenberg U, Petersen MB, et al. Investigation of deletions at $7 \mathrm{q} 11.23$ in 44 patients referred for Williams-Beuren syndorme, using FISH and four DNA polymorphisms. Hum Genet. 1997;99:56-61.

20. Elçioglu N, Mackie-Ogilvie C, Daker M, Berry AC. FISH analysis in patients with clinical diagnosis of Williams syndrome. Acta Paediatr. 1998;87:48-53.

21. Mila M, Carrio A, Sanchez A, Gomez D, Jimenez D, Estivill X, et al. Clinical characterization, molecular and FISH studies in 80 patients with clinical suspicion of Williams-Beuren syndrome. Med Clin. 1999;113:46-9.

22. Beust G, Laccone FA, Del Pilar AM, Wessel A. Clinical aspects and genetics of Williams-Beuren syndrome: clinical and molecular genetic study of 44 patients with suspected Williams-Beuren syndrome. Klin Padiatr. 2000;212:299-307.
23. Ingelfinger JA, Mosteller F, Thibodeau LA, Ware JH. Biostatistics in clinical medicine. 3.ed. New York: McGraw-Hill; 1994. p. 332-64: Using meta-analysis for research synthesis: pooling data from several studies.

24. Perneger TV. "What' s wrong with Bonferroni adjustments." Brit Med J. 1998;316:1236-8.

25. Gordi T, Khamis H. Simple solution to a common statistical problem: interpreting multiple tests. Clin Ther. 2004;26:780-6.

26. Preus M. The Williams syndrome: objective definition and diagnosis Clin Genet. 1984;25:422-8

27. Health Care Supervision for Children with Williams syndrome American Academy of Pediatrics. 2001;107:1192-204.

28. Sugayama SMM, Koch VHK, Furusawa EA, Leone C, Kim CA. Renal and urinary findings in 20 patients with Williams-Beuren syndrome diagnosed by fluorescence in situ hybridization (FISH). Rev Hosp Clin Fac Med S Paulo. 2004; 59:266-72,2004.

29. Conway JR, Noonan J, Marion RW, Steeg CN. Myocardial infarction leading to sudden death in the Williams syndrome: report of three cases. J Pediatr. 1990;117:593-5.

30. Imashuku S, Hayashi S, Kuriyama K, Hibi S, Tabata Y, Todo S. Sudden death of a 21-year-old female with Williams syndrome showing rare complications. Pediatrics International. 2000;42:322-4. 